\title{
FMC における制御システムと制御要素*
}

\author{
坪井定一块片岡秀晃 ${ }^{* *}$ 藤井敏 夫***
}

Key words: hierarchical control system, software concept, control element, machining space controller, master-slaved $\mathrm{NC}$, divided type high frequency power transformer, wireless optical transmitter.

\section{1. ま え がき}

葆来, 多量生産が主流であった機械工場の技術指向が 多種少量生産に移行しつつあるのは, 製品の多様性, 新 钼性を次々に求める市場ニーズが顕在化してきたことに 上る.この市場ニーズの変化に呼応して生まれたFMC ま，多様な製品を扱うことを目的としている．その実現 ゆた的に各機構の複合化とモジュラ構造が提唱され探求 はれつつある(表1).

一方 FMC の制御といら面から眺めてみると, その制 御装置群が果たすべき要求品澌は以下の 3 項目に集約す にことができょう。

(1) 多品種少量生産を満足する柔軟性と迅速性

(2) 生産量の增大, 品種の変更, 生産技術, 制御技術 の進歩などを柔軟に受け入れるシステムそのものの 拉張变更の容易性

(3) 効率的な運転を保つためのデータ収集システムの 充実と豊富なマン・マシンコミュニケーション 現在研究開発しつつある制御システムについてその研 究開発のポイントを以下記述する.

\section{2. システムの構築}

\section{1 柔軟性と迅速性}

FMC の柔軟性を実現するために各機能のモジュラ構 造が提唱されていることは前にも述べた。

この機能モジニールが作業目的によってその構成内容 を変化させて「マシン」を形成するが，この「マシン」 を制御するには各モジュールに自分自身の制御構能の大 部分を埋め计み，上位の制御装置からはなるべく簡単な 指令值のみを受けるよらにすることが望ましい. 幸いな ことにマイクロブロセサに代表される技術の進歩によ り，高機能の制御装置を小形軽量に実現させることが可 能になったので, 上に述べたような各機能モジュール のインテリジニントコントローラの分散配置が可能と

* 原稿受付 昭和 58 年 5 月 30 日.

** (株)安川電機製作所行橋工場 (行橋市西宮市 2-13-1)

*** (株)安川電機製作所東京支社: (東京都千代田区大手町 1-6-1, 大手町ビル)
なった。

図 1 はFMC 制御システムのハードウェア構成を示し たもので, この図では各機能モジュールのインテリジェ ントコントローラは，レベル 4 のユニット管理装置とし て表現されている。このニニット管理装置複数個が 1 台 のセル管理装置 (レベル3) で制御され, さらにこのセル 管理装置複数台が 1 台の機構管理装置 (レベル 2)で制御 されている。

このようなシステムを階層構造の制御システムと呼ぶ が，これにより，各「マシン」の組替えごとに大量の制 御プログラムを移動させることなく，独立性の強い制御 システムを構築することができる，またその結果として 予期しない工程の变更やローカルなトラブルが起こった 場合でも, 速やかに工程を組み替えたり，各機構別ある いは機能別の運転が可能になる.

このようにして制御の柔軟性と迅速性を同時に満足さ せることができる。

\section{2 拡張・変更の容易性}

FMC は市場ニーズの変化に 柔軟に対応しなければな らない. 一方, 製品のライフサイクルは短く, かつその 種類は多様化の傾向にある。乙たがって FMC は次々に 要求されるであろら生産量の増大, 品種の変更などを柔 軟に受け入れる必要がある。本節ではこのような観点か らシステム設計に際して, 重要な「標準化」と「ソフト ウェアの開放」について述べる.

1）標準化・ユニット化

前節 2.1 で, 階層構造の制御システムが FMC 運転の 柔軟性，迅速性といら点から見て優れていることを説明 したが，このシステムは各機構単位，機能単位で独立し ているという点から，本節で取り上げた拡張変更の容易 性といら点から見ても非常に有利である．但しこの優位 性を発揮させるためには，各情報伝送ラインから切り離 表 1 市場ニーズの変化とその対応

\begin{tabular}{|c|c|c|}
\hline 品 & 機 械 機 構 & 制御システム \\
\hline $\begin{array}{l}\text { ·多様性 } \\
\cdot \text { ・ライフサイクルの短縮 }\end{array}$ & $\begin{array}{l}\text { ·複合化 } \\
\text { ・モジニラ化 }\end{array}$ & $\begin{array}{l}\cdot \text { 柔軟性と迅速性 } \\
\text { ·拡張・変更の容易性 } \\
\cdot \text { •データベース }\end{array}$ \\
\hline
\end{tabular}




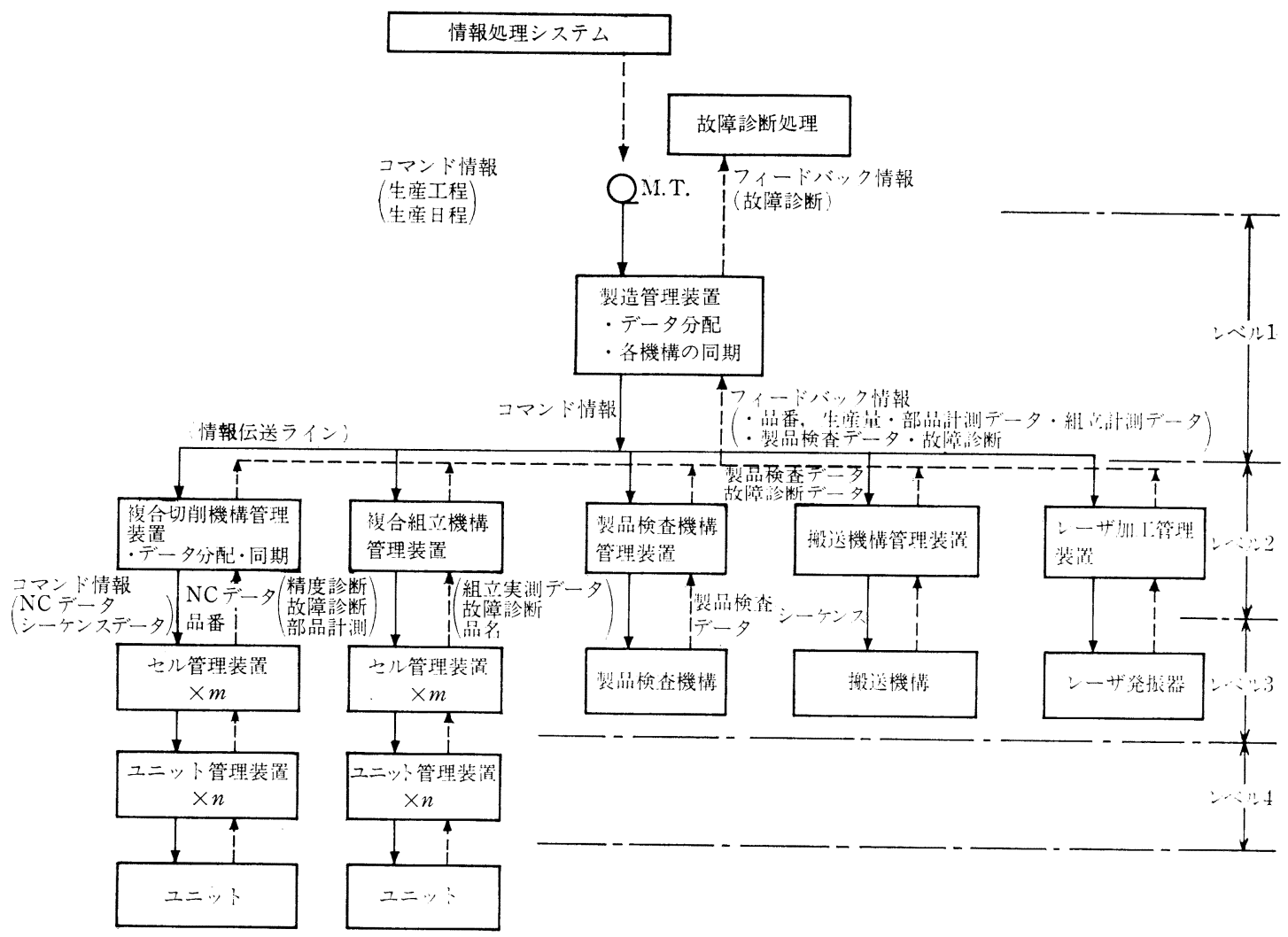

図 1 制御システムのハードウェア構成

したり, 又は追加したり，あるいはまた機能モジュール 内のインテリジェントコントローラを埋め変えたりする ことが容易に害行できなければならない。

そのためには制御信号のレベルや伝送手順などはでき る限り標準，規準を用いるべきであり，一時的な，ある いは局部的な都合で，非標準の「最善策」を採用すると たちまちシステムが固定化されてしまい，以後の改造を 拒絶するようになる。

2）ソフトウェアの開放

システムの改造はソフトウェアの書換光から始まるの が常である. 改造の必要性はその使用者が一番良く知っ ているのでソフトウェアの改造は使用者自身で行うこと が望ましい。

FMC のソフトウェアは

○直列型制御プログラム

○並列型制御プログラム

○管理プログラム

に大別することができるが，以下に各グループごとに 「ソフトウェアの開放」の考光方を述べる．まず最初の直 列型制御プログラムとは各タスクの起動順序など実行順 序の決まっているもののことで, ローカルな作業スペー
スでの制御命令はこのタイプに属する。この種のプログ ラムは通常低レベルの計算機言語で書かれることが多い ので, 使用者自身がこの言語清通することが望ましい，

第 2 の並列型制御プログラムとは異所で同時に起こる シーケンスを制御するためのプログラムのことで，これ は多くの PC (Programmable Controller)が採用して いるスキャン一解読処理タイプのプログラムで組むのが 良い，PC言語を採用すれば使用者は言語的な負担を負 らことなく，必要な制御シーケンスを自由温み替える ことができるので，考慮すべきことはマン・マシンコミ ニニィーションのニーティリティのみである.

最後の管理プログラムは通常 COBOL に代表されるい わゆる高級言語で組まれることが多い。そうしてこれら のプログラムは「計算機屋」が処理することが通常なの で使用者は「計算機屋」に対して自分の要求仕様を滴確 に表現すれば良い。

\section{3 データベース}

表 1 の最後に「データベース」を揭げているが，その 必要性の背景として三つの項目を上げることができる (表 2).

まず第1に上げなければならないのは, PL 問題やフ 
表 2 データベースの必要性

\begin{tabular}{|c|c|}
\hline 目 & 的 \\
\hline ○PL 問題 & 保存義務 \\
\hline $\begin{array}{l}\text { ○柔軟・迅速な生産体制 } \\
\text { 。管理の原則 }\end{array}$ & $\begin{array}{l}\text { システムの総合判断 } \\
\text { 効率化の追求 }\end{array}$ \\
\hline
\end{tabular}

隹トレコーダなどにその例を見るようなトラブル解明 Dための品質データの保存といらことで，今後ともその 北要性は增大してくると考光られる。

第 2 亿考慮するべき面は，FMC に要求されている柔 般，迅速な生産体制を維持するためのデータベースとい らことで, 2.1 節で述べた階層構造の FMC 運転のため には必要な時に必要な所からデータを呼び出すことがで にるようにすることが必要不可欠である。

そらして最後に「管理の原則」といら面であるが，こ 几はあらゆる生産活動が日常行っている高効率・低コス トの追求のためのデータ集めであり, それは製品の品質 青報，作業工程，進捗状沉，マンンの稼動状況，仕掛品 青報, 資材管理情報から始まって，公害情報や各個人の 勤意情報にまで及ぶ。

図 2 がこれらの目的のために種々の管理データをオン ラインで集めるためのシステム構成を示している，同図 こ示されているように, 制御データは上位の管理装置か

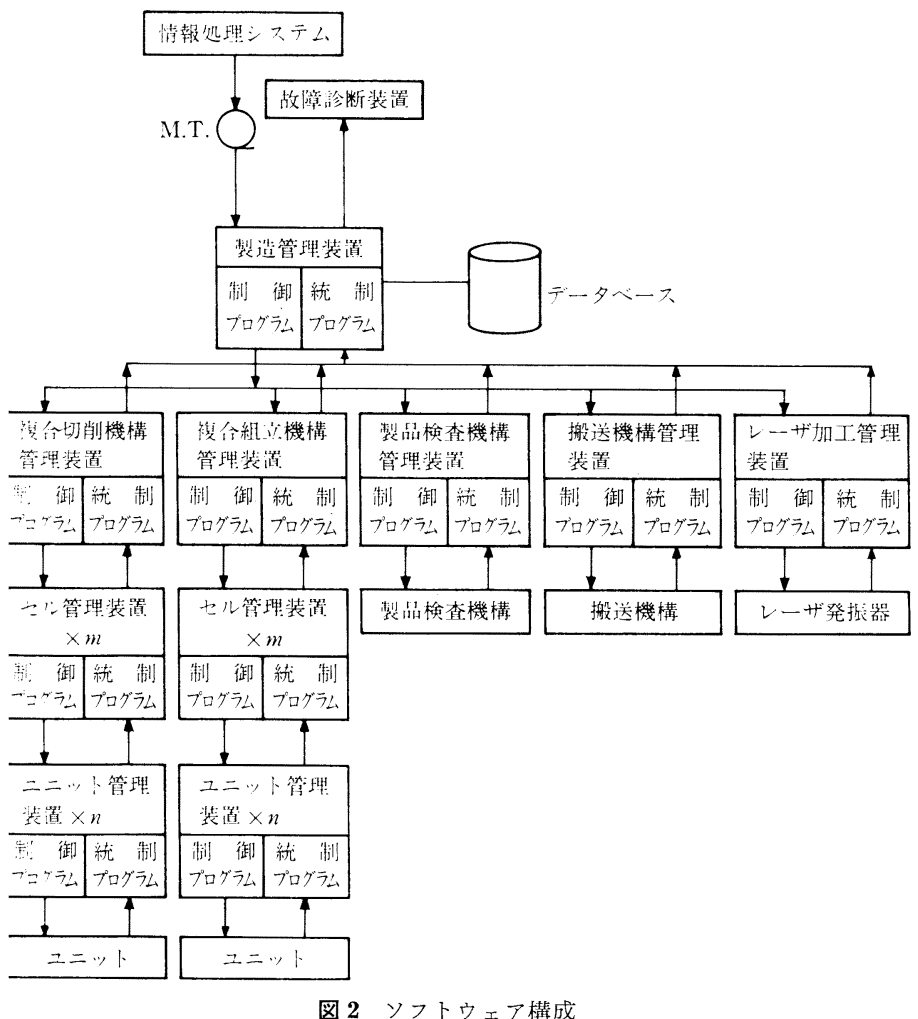

図 2 ソフトゥェア構成
ら下位の管理装置に流れるのに対して, ここで述べた統 制データは，下位から上位へ伝详されデータベースを構 築する。

\section{3. ソフトウェア体系}

前章で FMC の制御システム構築の考え方を述べた が，本章ではFMCのソフトウェアについてその基本概 念を述べる。

FMC はその目的からソフトウェアを頻繁に変更しな ければならないが，その手段は今から処理しようとする ワークの運転プログラム（例えばNCプログラム）の差 換えによって行う。

これはマスプロ生産ライン構築の概念と異なるところ で，マスプロの場合には制御プログラムと運転プログラ ムとの分離は必ずしも必須の条件ではない。これに対し て FMC の場合には，処理内容はすべて運転プログラム で表現するべきで，制御プログラムでそれを表現しては ならない，それは丁度 2.2 節の 1) 標準化・ニニット化 の所で述べたのと同じ理由で, 現在考えているワーク群 では皆同じだからという理由で，個々の運転プログラム では表現せずに，制御プログラムで処理するようにして

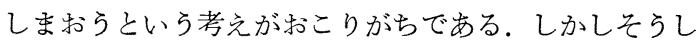
てしまうと,次に全く新しい製品を作ろらとする場合に， 大変な労力をかけてシステムの変更を しなければならなくなる。

同じような理由で，運転プログラム と制御データも，分離しておかなけれ ばならない，例党ば切削用の NCプロ グラムを書く時には, 工具データは手 元にないことが普通なので，そのデー タを分離しておくということは NCで は常識になっているが，搬送用のパレ ット番号となると運転プログラムに書 こうとすることがあるが，このような やり方はシステムの柔軟性を損なうこ とになるので注意が必要である。

このように FMC の運転プログラム は種々の運転環境から独立していなけ ればならず,

(1) 自動，手動などの運転モード

(2) 同じ作業ができる場所が数か所 ある場合にそのどこを選ぶかとい 万選択

（3）他製品との処理順序 などによって別々の運転プログラムを 必要とするとなると，著しく不便なも 


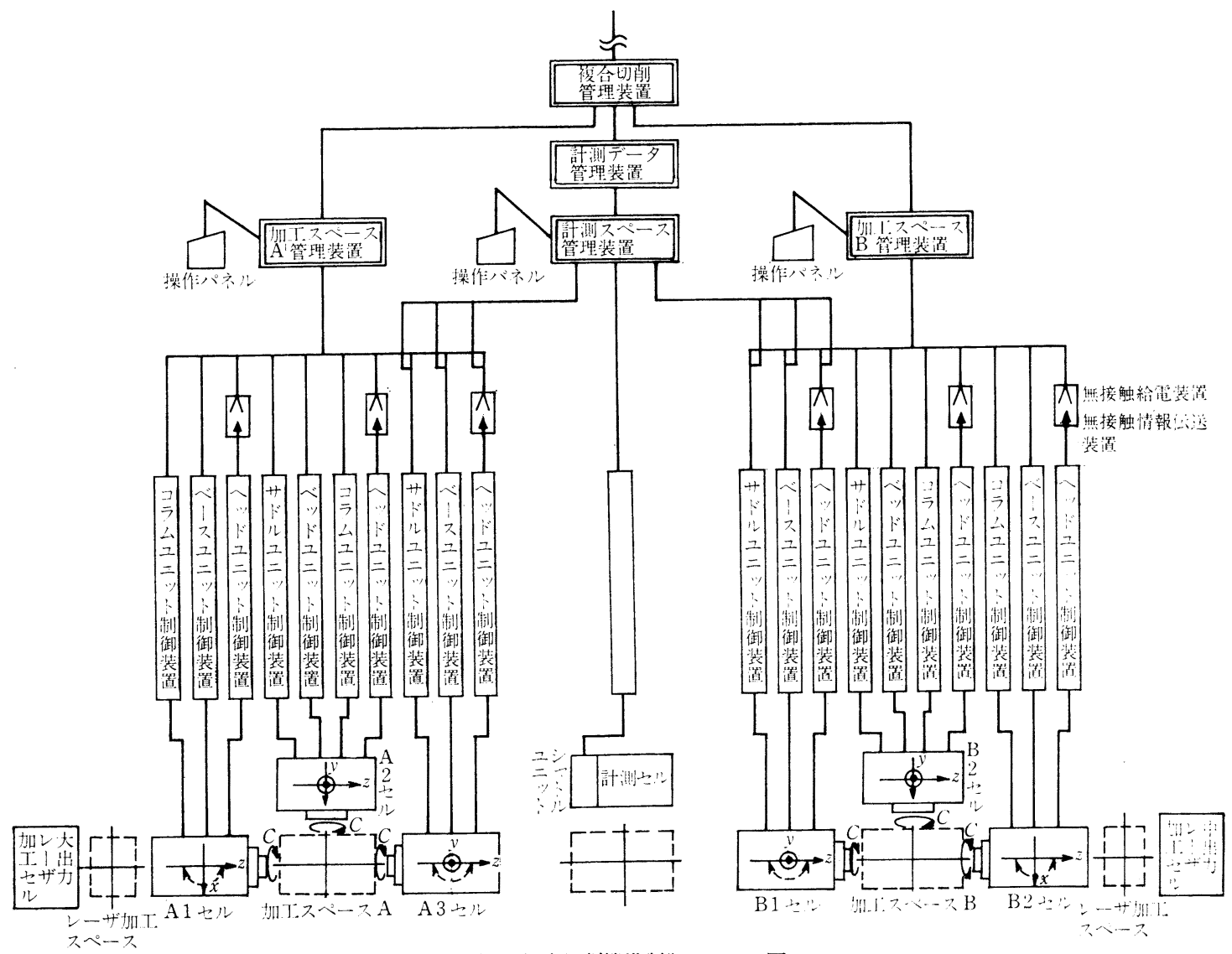

図 3 複合切削機構制御ブロック図

のになってしまう。.

最後に上げた (3) 他製品との 処理順序という所は, シ ステム設計上最も工夫を要する所で, それは製品 $\mathrm{Q}$ の処 理中に次の製品 $\mathrm{R}$ に対する準備作業や，前の製品 $\mathrm{P}$ に 対する後処理などを実行するという FMC 独特の機能が 必要となるからである．これは柔軟性と共に必要として いる FMCの迅速性を実現させるために是非とも必要な 機能である。

\section{F MC 制御の要素技術}

FMC の制御システムを構成する要素技術は広範囲に わたっている. その内の多くのものがすでに制御装置, 駆動装置の中に組み込まれて，筑波実験プラントの制御 システムに適用されている。ここでは要素技術のうら主 として複合切削機構に適用したものについて述べる。

\section{1 制御システムに対する要求}

FMC の制御に対しては, 次のような要求が示されて いる.

（1）制御システムは複合製造システム内の製造設備を
制御し運転できること。

（2）独立性の強い機能別にモジュール化されているこ 之.

（3）モジュール化した機能単体で運転可能であるこ 之.

（4）制御システムは上記モジュールを組み合わせ結合 した多階層システムの構成を備えていること。

(5) オンライン・リアルタイム制御であること.

（6）各階層間の制御はオープンルーブで構成され，コ マンド情報の伝達はTopから Bottom への 1 方向 のみの構成であること.

\section{2 機械システムとの適合}

一方, 複合切削機構は, 図 3 に示すように加工セルを T型配置し（加工セルに囲まれた空間を加工スペースと 呼ぶ), 加工セルは機能ニニットを自動交換し，加工ス ペースの要求する機能を構成するようになっている.

制御システムに対する要求条件を満足し，機械システ ムに適合させるために，次のような検討がなされた。

(1) 加工スペースの管理・数値制御方式 


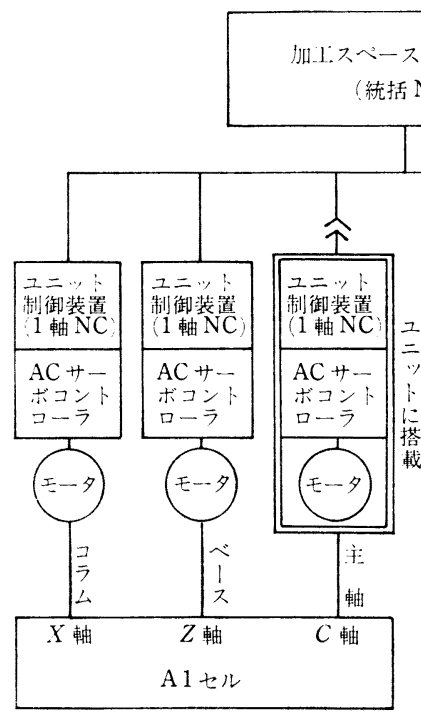

ら分散形システム

(2) 各機能ユニットの駆動方法

モータ容量, 回転数がニニットごとに異なる

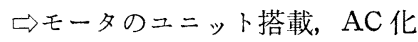

（3）各機能ニニットへの電源および情報の供給方法

$\Rightarrow$ 無接触化

（4）主軸の高速化と位置決め機能

$$
\text { のデュアルモードモータ }
$$

以上いずれも小形化が必須条件である。

\section{3 分散形数值制御 (NC) システム}

モータのサーボドライブを含むシステムブロック図を 図4に示す.

分散形 NC システムは，1軸のみを単独に制御する $\mathrm{NC}$ と，その 1 軸 NCを多数軸統括制御する統括 NCか ら構成される。1軸 $\mathrm{NC}$ は主軸 ( $C$ 軸), 送り軸に適用さ れ, 主軸用 1 軸 $\mathrm{NC}$ は主軸ユニットに搭載されている.

統括 NC は上位計算機より送られる加工プログラム, 制御データなどの情報により加工スペースの軸構成を決 定し, 距離, 速度, 加速度などの指令を各軸の 1 軸 NC に出す，各軸はその指令に基ついてモータを制御する。 制御軸は 10 軸，同時 4 軸の制御が可能である.

この NCシステムは, 制御軸をほかの統括 NC の管理 に切り替えることが可能である. 例えば，A 3 セルおよ び B 1 セルの各 3 軸を計測スペースの管理に切り替え て, 計測スペース管理装置の指令により, 計測セルと共 にA 3，B1セルを制御することがでさる.

実験プラントでは，1 軸 NCに分散 PC（シーケンサ） を内蔵した制御装置をユニット制御装置と呼び，これは
図 5 無接触給電装置 (2 次倒)

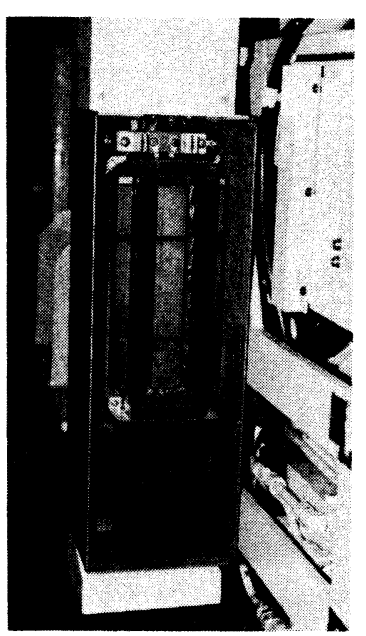

表 3 無接触給電装置の仕様

\begin{tabular}{c|l}
\hline 変压 器 & \multicolumn{1}{|c}{ 高周波インバータ } \\
\hdashline 制御電源用 & 主電源用 \\
$1 \mathrm{kVA}(\mathrm{AC} 100 \mathrm{~V}, 50 \mathrm{~Hz})$ & 容 量: $12 \mathrm{kVA}$ \\
$\begin{array}{l}\text { 主電源用 } \\
12 \mathrm{kVA}(5 \mathrm{kHz})\end{array}$ & 出力電圧: $270 \mathrm{~V}$, 方形波電圧 \\
\hline
\end{tabular}

図 1 のニニット管理装置に相当する. また統括 NCにPC を内蔵した装置をスペース管理装置と呼び，これは図 1 のセル管理装置に相当する.

\section{4 無接触給電装置}

ユニットに電源を供給する装置である。この装置は分 割形高周波変圧器であって, 変圧器の 1 次側巻線と 2 次 側巻線（図 5）とを独立に分け，1 次側を加工セルに， 


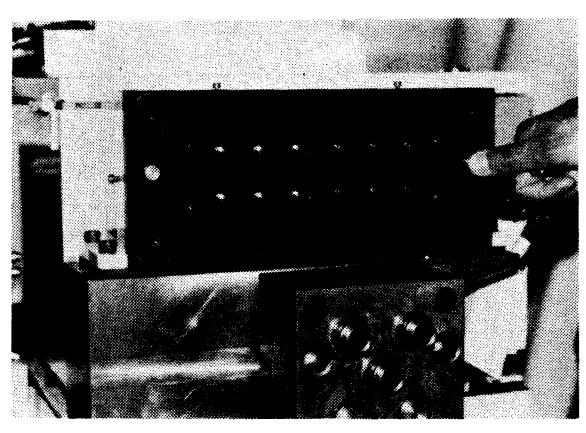

図 6 無接触情報伝送装置

表 4 無接触情報伝送装置の仕様

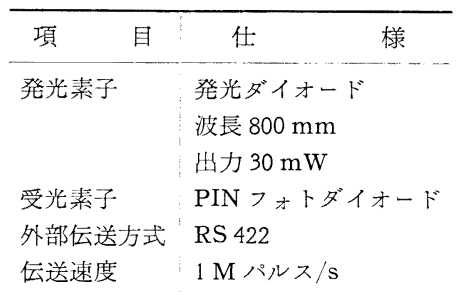

2 次側をユニット側に取り付けて，ニニットが加工 セルにセットされた時に変圧器を構成するようにな っている．仕様は表 3 に示す.

\section{5 無接触情報伝送装置（図 6)}

機能ユニットに搭載された 1 軸 NCに NC 信号(情報) を伝送する装置である．伝送はフォトカップリングによ る. 仕様は表 4 に示す。

\subsection{AC サーボモータコントローラ}

$\mathrm{AC}$ サーボモータコントローラは主軸用, 高速主軸用, 送り用功ある。高速主軸では表 5 の仕椂に示す通り高速 と割出し位置決めの機能をあわせ持ち, しかもトルクも

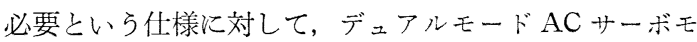
ータコントローラを開発した。

以上簡単に述べたが，主軸ニニットに各装置が搭載さ れた状態を図 7 に示す。

\section{F MC 制御システムのソフトウェア}

FMC 制御システムのソフトウェアは, 図 2 に示すよ らにモジュール化されている，個々のソフトウェアは独 立性を高くしており，モジュール単位で切り離しても単 独で機能を遂行できるよう構成されている.

製造管理装置のソフトウェア構成は, 前論文の「FMC に拉けるトータルンステム」で述べられているので, 本 章では, 複合切削, 複合組立などの下位機構管理装置の ソフトゥェアについて, 複合切削機構を例にとって説明 する。

表 $5 \mathrm{AC}$ サーボ装置の仕様一覧表

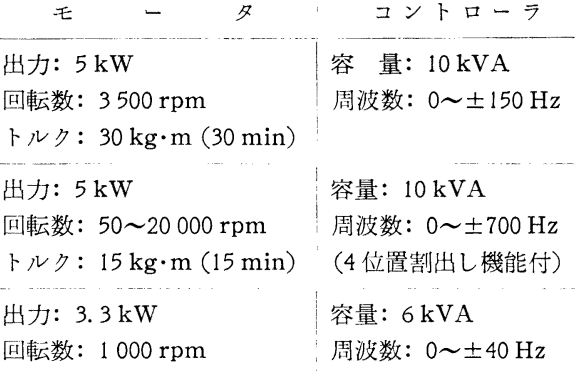

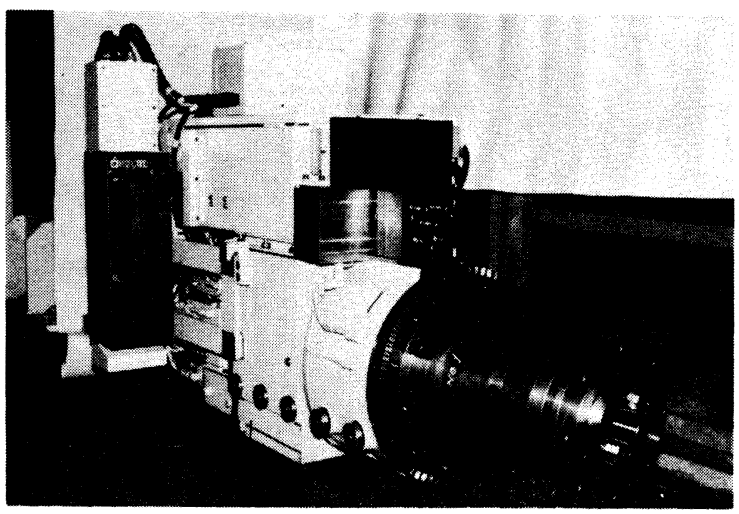

図 7 主軸ユニット

\section{1 複合切削機構管理装置のソフトウェア}

複合切削機構管理装置のソフトウェア内容について説 明する。

1）生産スケジュール管理

加工スケジュールデータの進抄状沉の管理・制御を行 5 .

2) ワークプログラム管理

1 ワークの加工工程順に, FMC 制御コマンド（加工, 計測, 搬送, システム命令など) で記述されているワー クプログラムを，コマンドごとに解読を行う.

3）ジョブプログラム分配

モジニール化 (FMC 制御コマンド)された加工, 計測 用プログラムで, 1 加工単位やサブプログラム単位に記 述されているジョブプログラムを DNC 結合された加工 スペース管理装置などへ1 ジョブ単位でデータ分配を行 5 .

4) システム命令処理

ワークプログラムに記述されているシステム命令（制 御コマンド）を, 管理装置内でデータ処理, 演算処理な どを行う。

5）前準備作業指示

準備作業ステーションでのチャッキング情報やパレッ 
ト情報などを，データベースより取り出して，CRTへ 作業指示表示を行う。

6) 生産統制

下位管理装置加, 完了信号, 合否判定信号や加工精 度データおよび故障診断データなどを受け取り, 故障診 断, 生産実績, 運転状況モニタリングなど, システム全 体の生産統制を行ったり, 製造管理装置への報告を行う.

7) 異常処理

非常停止などの緊急事態に対して，他機構への影響を 最少限にするための渾転モード変更 (システム運転セ機 構別運転) や生産スケジュールの変更を柔軟かつ迅速に 行う.

8) データベース

加工目的に応じて離合集散を行う機能ユニットやマガ ジンなどに付加されている加工補助データや工具寿命デ ータおよび構成精度データなどをファイル化し, 必要に 応じて呼び出し, 登録, 更新を行う.

9）その他

複合切削機構には, マン・マシンコミュニケーション をより密接にするための各種プログラム（OS, UTILITYなど）が準備されている.

\section{2 分散形数值制御装置のソフトウェア}

分散形数值制御装置は, 図 3 に示すように, 軸を制御 するユニット制御装置と，それらを統括制御する加工ス ペース管理装置に分けられる。

以下ソフトウェア内容について説明する.

1) DNC 制御

複合切削管理装置と加工スペース管理装置間のオンラ インデータ伝送をモデムにより行う. 複合切削管理装置 より転送されたジョブデータは，一時メモリーに蓄えら れ，1ブロック単位にデータ処理され，下位のニニット 制御装置へ送られる。

2) ユーザマクロ

加工スペース管理装置のニーザマクロ機能により, 工 具刃先位置修正, 旋回 $B$ 軸制御, 構成精度補償などを行 うことができる。

3) 軸宣言

加工スペース管理装置の制御軸数は最大 10 軸, 同時
制御軸数は最大 4 軸である. 任意の軸の組合せで同時制 御を行ら場合には, 最大 10 軸の中から, どの軸を $X, Y, Z$ および $C$ 軸（または主軸）にするかを宣言する。

4) 主軸制御

同一加工スペース空間において，2本のドリルを別々 の機能ユニットに装着し, 異なった回転数で制御する主 軸同時 2 軸制御や, 高速主軸 $(20000 \mathrm{rpm}$ ) 制御および 主軸/ $C$ 軸制御などを行う.

5) シーケンサ

加工スペース管理装置と機械の間の信号を円滑に処理 するためのシーケンス機能 (PC) やニニット制御装置 の専用シーケンス機能 (分散 PC) をもつ.

6) ユニット制御装置

加工スペース管理装置の管理下で各軸を 1 対 1 で制御 する。すなわち，それ自身が一つのまとまった 1 軸専用 の NC 装置である.

7）旋盤系およびマシニングセンタ系の併合機能 複合切削機構で要求される加工は丸物, 角物があり, 旋盤用およびマシニングセンタ用の両方の機能が必要と される。

8）その他

上記以外に, $\mathrm{NC}$ 装置は, 軸切替機能, レーザ加工機 能, 精度補償機能および適応制御機能などを有している.

\section{6. む す び}

以上 FMC の制御システムと制御要素について述べて きたが，制御要素についてはすでに製作を終わり，機械 に組み込んで組合せ試験を実施している.

制御システムのソフトウェアについては, 筑波実験プ ラントに拈ける運転研究で検証されるが, 現在は個別試 験の段階でデバッグを行っている.

\section{参 考 文 献}

1）特開昭 56-102455「複合生産システム」

2）機械技術協会生産技術調查分科会監修：日本の FMS 事例 集, マシニスト出版 (1982).

3）品質管理 - 特別企画 “FMS と品質管理”, 34, 3 (1983).

4）情報処理，特集 “設計生産の自動化”, 24, 1 (1983).

5）安川電機 “メカトロニクス技術特集号”，46，4 (1982). 